\title{
The Utility of Vygotskian Behavioral Criteria in the Early Childhood Classroom: Learning from Non-compliance
}

\author{
Laura Reynolds-Keefer \\ University of Michigan-Dearborn \\ 19000 Hubbard Drive, Fairlane Center South, School of Education \\ Dearborn, MI, 48126, USA \\ E-mail: 1rkeefer@umd.umich.edu
}

Received: August 29, $2011 \quad$ Accepted: October 24, $2011 \quad$ Published: December 30, 2011
doi:10.5539/jedp.v1n1p184

\begin{abstract}
Non-compliant behavior in young children is consistently an area of concern for the teachers and caregivers of young children. These behaviors can disrupt learning, teaching and positive social interactions, increase referrals for special services, discourage the teacher, and reduce positive interactions with family. Behaviors such as defiance and non-compliance also present early childhood educators with difficult situations in their classrooms, are often considered indicators of hyperactivity, attachment or relationship disturbances, and a predictors of later academic and socio-emotional problems. Despite being a common concern on the part of both families and caregivers, relatively few tools exist that give early childhood educators ways in which to analyze these difficult behaviors. This study explores the strengths, limitations and utility of the behavioral categories created by Vygotsky in the documentation and analysis of non-compliance in young children in the modern early childhood classroom.
\end{abstract}

Keywords: Vygotsky, Non-compliance, Defiance, Toddlers, Observation

\section{Introduction}

Non-compliant behavior in young children is consistently an area of concern for the teachers and caregivers of young children. Noncompliance or defiance refers to those instances when a child intentionally does not perform a behavior that has been requested by a parent or other adult (Kalb \& Loeber, 2003). Non-compliance can disrupt learning and positive social interactions, increase referrals for special services, discourage the teacher, and can reduce positive interactions with family (Dodge \& Price, 1994; Honig, 2009). Defiance and non-compliant behaviors present early childhood educators with difficult situations in their classrooms, and can play a part in poor academic performance (Brinbaum, et al., 2003; Delany-Black et al., 2002), aggression (Denham \& Burton, 2003; Keenan \& Shaw, 1994), and poor socialization with peers (Buysse, Goldman \& Skinner, 2002; Izard et al., 2001; Killen \& Smetana, 1999; Schultz, Izard, \& Ackerman, 2000; Schultz, Izard, Ackerman, \& Youngstrom, 2001).

Understanding and strategizing about how best to manage non-compliant behaviors in young children and exploring how best to help early childhood educators in documenting and recording behaviors is an essential part of that process (Honig, 2009). Assessment tools such as Child Behavior Checklist (CBCL) (Achenbach \& Edelbrock, 1983) have been useful, but more exploration of how teachers can use educational and behavioral theory to assist in documenting and analyzing non-compliant behaviors in their classrooms may help teachers clarify the child behaviors, their significance, and improve outcomes. The purpose of this study is to explore the utility of using Vygotsky's categories of non-compliant behavior in preschool children enrolled in a university childcare setting.

\section{Literature}

\subsection{Behavior and Socio-emotional Development}

Noncompliant behavior has been an area of substantial research and inquiry, especially as it relates to behavioral management and socio-emotional development. Because the issue extends to behavior outside the classroom, research exploring parenting and discipline style, and levels of parental monitoring (Ceballo, Ramirez, Hearn, \& 
Maltese, 2003) have addressed the issue of non-compliance (Hughes \& Ensor, 2006; Kilgore, Snyder, \& Lentz, 2000). The impact of parenting and discipline styles inform our understanding of non-compliance and defiant characteristics in children (e.g., Braungart-Rieker, Garwood \& Stifter, 1997; Kuczynski \& Kochanska, 1990; Smith, Calkins, Keane, Anastopoulos \& Shelton, 2004), and provide families, parents and educators with strategies for effectively managing disruptive and defiant behaviors is critical (Honig, 2009).

An important part of the discussion of defiance includes children's ability to regulate their emotions (Kochanska, Coy, \& Murray, 2001; Mize \& Cox, 1990; Denham, 2003). The ability to self-regulate negative reactivity correlates to later social competence. Infants and toddlers found to have difficulty reducing arousal to frustrating situations under research conditions were more likely to be noncompliant to adult requests at 18 months of age (Sifter, Spinrad, \& Braungart-Rieker 1999). Rates of non-compliance are not only related to discipline style, but also to child temperament and the development of self-regulatory skills.

The development of social competence, friendships and social acceptance is also important in considering noncompliant and defiant behavior. Burton and Denham (1998) described non-compliant children as exhibiting socially disturbing behaviors including hostility, inability to play, inappropriate affect and unprovoked aggression, and the relationship of those behaviors to social skills. Whether social competence is viewed as a matter of problem-solving and interpersonal ability (Denham \& Burton, 2003) or in terms of peer relations and self-management (Buysse, Goldman \& Skinner, 2002), the inability to tolerate frustration, follow social norms, or comply with expected behaviors is usually associated with aggressive behavior. Teacher actions to assist children in establishing and maintaining friendships have been emphasized avoid "behavioral, academic and social problems" and to thereby temper non-compliance (Buysse, Goldman, \& Skinner, 2002).

\subsection{Rates of Non-compliance}

Studies relating to difficult behaviors and non-compliance in young children typically have not focused on rates of non-compliant behavior. There have been some studies that consider non-compliance in relation to issues such as age (Calkins, et al, 1999; Kuczynski \& Kochansha, 1990), gender (Honig \& Wittemer, 1994), level of child ability or disability and parental interaction or style (Schneider-Rosen \& Wenz-Gross, 1990). Research on non-compliance has incorporated naturalistic observations on children. For example, in a study of 36 children ranging in age from 45 to 78 months, Atwater \& Morris (1988) found an average compliance rate of $77 \%$ to teacher commands. MacKenzie-Keating, McDonald, Tanchak and Erikson (1996) also conducted research on the frequency of complaint behaviors in observations of 144 preschool children, and found that the mean rate of compliant behavior was $84 \%$. The authors note that few studies on non-compliance report rates of non-compliance in children in a naturalistic classroom setting (p. 92). When such data is collected, it frequently is reported as secondary data and not as the primary concern, and includes no information relating to teacher perspective or reflection on the behaviors observed.

\subsection{Vygotsky and Non-compliance}

Vygotsky (1997) viewed non-compliant behavior as evidence the child experiencing the fundamental change and conflict in relation to development. The changes during these critical developmental periods are dramatic, and Vygotsky described development during critical periods as "stormy, impetuous and sometimes catastrophic." He stated that these periods and their associated characteristics are not "diseases" or deviations from the normal path of developmental peaks for the child (p. 191), but offer insight into the inner life of the child. The impact of these changes appears most distinctly in the six critical periods, one of which occurs at age 3 which is focused on the relationship between the child and adults. These behaviors all present challenges, but the emergence of non-compliance at age three presents a particularly formable challenge for early childhood teachers (van der Veer \& Valsiner, 1994).

In exploring the utility of Vygotsky's critical stages and the associated behaviors, this study sought to consider whether the terms are useful descriptors of early childhood behaviors. The six behaviors listed in Table 1 are Vygotsky's original terms describing the behaviors of children during the "critical" period of age three.

\section{Insert Table 1}

These defiant behaviors are the focus of the critical period of age three because their presence suggests the child experiencing the fundamental change and conflict with adults at this point in development. These behaviors represent, in Vygotsky's dialectical approach, development toward autonomy from adults and authority figures. For Vygotsky, each of these challenging behaviors represents a specific avenue of growth and independence, and is developmentally critical. This study considers if using Vygotsky's categories of non-compliant behavior in table 1 has utility in the early childhood classroom and might ultimately prove a useful tool in the analysis of 
child behaviors in relation to developmental trends and needs.

\section{Methods}

\subsection{Participants and Sample}

In this study, I observed the outdoor play of two classes composed of 27 children ranging from 35 to 44 months at a childcare center. The children represented diverse ethnic and socio-economic backgrounds. The class included 12 girls and 15 boys. Of the 27 children, 6 children were African-American, and one child was Asian. I met with the director of the child development center and the head teacher to discuss the nature of the study, as well as with three assistant teachers. During days 1-5, I observed independently, and during days 6-10 I observed with the second researcher while each maintaining independent notes. Throughout the study, all observations were recorded on the Non-compliant Behavior Worksheet (NBW) using Vygotsky's terms detailed on Table 1 as codes (Reynolds-Keefer, 2005).

\subsection{Data Collection}

I conducted observations for 30 minutes a day for 10 days during morning outdoor play. The playground area included balls, cones, and tricycles, as well as climbing equipment, a picnic table, swings, a garden, and a large grassy area. Children had access to imaginary play structures as well as a water table and a sand box. Before observing, I spent two days with the second researcher reading and discussing the categories and definitions used by Vygotsky to describe terms that we would be assigning to behaviors considered defiant, as well as the nature and examples of defiant behavior. After initial discussions and clarifications, the second we read through examples of behaviors we felt were examples and non-examples of each of Vygotsky's categories, and then discussed why the corresponding Vygotskian category would best apply. We then practiced observing a class during outside play together, and coded defiant behaviors that emerged and discussed our observations. Joint observations resulted in good agreement using the Vygotskian categories of defiance. Observations at the child development center were not video recorded.

\section{Insert Table 2}

\section{Results}

During the 10 days of observation, 55 behavioral incidents were observed. During days 1-5, I observed and coded 29 incidents of defiance, and in days 6-10, the second researcher and I observed and coded 26 incidents. The results of these observations have implications on two levels: the observability and accuracy of the Vygotskian terms, and the utility of these categories from the point of view of the early childhood educator. In analyzing the data, Vygotsky's conceptualization of the critical period showed both strengths and weaknesses when used to analyze and better understand defiant incidents. Analysis of the 55 behavioral incidents showed that Vygotsky's behavioral terms were generally descriptive of defiant behaviors and served to capture the incidents of defiance observed on the playground. All the terms were observed in the behaviors of the children, and no term was observed on a single occasion.

Stubbornness, protest and obstinacy were the most observed behaviors. Of the 55 defiant episodes, 14 were identified as stubbornness, 11 as protest, and 10 as obstinacy. Stubbornness presented frequently in playground conflicts as inability to change or reconfigure thought. In showing stubbornness, children conducting an activity or action in one way refused to change their initial plan, refused to consider the opinion or possible utility of the idea of another even if it was clearly better. An example of stubbornness occurred when a boy was asked to return to playing after a brief "time-out" sitting on a bench. The child refused to get off the bench, yet cried that he wanted to go back to playing in the sand. The teacher assured him that he could do that, and that his toys were still there and waiting. She asked again that he get up and go play, and he refused. In stubbornness, the intractability of the child's position created teacher frustration, as it demonstrated an unwillingness to admit error or apply logic. If the nature of the developmental task of three year olds according to Vygotsky is true, this unwillingness to surrender an initial position is a critical element of the formation of an independent self.

The second behavior frequently observed was protest, the verbal component of obstinacy. Vygotsky described protest as occurring when a child argues decisions and statements representing environmental norms or rules. Protest was observed as verbal expression, and, unlike obstinacy, did not necessarily result in a child breaking a rule or convention. The act of verbally stating disagreement is the key to this behavior. An example of protest observed during this study took place when a boy refused to leave the head of the line as the class prepared to go inside. The teacher restated the rule regarding student line leaders, and the boy began to argue that the rule was not applicable in the situation that day because he did not get a full turn to lead the class outside. He used verbal reasoning to argue his position against the decision of the teacher. Although the boy returned to the end of the 
line and did not pursue the conflict, the defiance was clearly present.

Obstinacy also appeared frequently, and presented as the unwillingness to comply with rules. Vygotsky described obstinacy as a child's "dissatisfaction" with the rules and conventions in the environment. Obstinacy is expressed in direct opposition to standards and expectations. In this study, obstinacy was typically observed when the child's wants and desires were prevalent, and dissatisfaction with rules resulted in refusal to comply. An example illustrating obstinacy occurred when girl persisted in her attempts to operate the sink used by the teacher to get water for the water table. After several reminders regarding the rule about staying away from the "big sink," the adult removed the child from the water play area. The child sat on the sidewalk quietly sobbing, and returned to the sink again and repeated the behavior the moment the adult left her side. The child refused to be deterred by the rules or norms and continued to pursue her desires by attempting to fill her pail herself.

\subsection{Accuracy}

Vygotsky's terms and descriptions of critical behaviors at the age of three were observable, but also accurate. During observations, there was always a term that accurately described each behavioral incident, and it was never the case that defiant behaviors occurred for which there was no applicable Vygotskian term. However, several behavioral observations appeared to involve multiple Vygotskian terms. Both researchers assigned a behavior to each incident that appeared to be the primary behavior. However, both researchers noted that the behaviors seemed to appear in clusters, with some pairs of behaviors appearing together frequently. At this stage of exploration, this has possible indications for future work that will be discussed in the implications section. The fact that we wanted to use more terms, and that we found multiple terms helpful in describing the behaviors observed indicates these descriptors are accurate and have potential utility.

Vygotsky's categories of defiant behavior were descriptive and accurate, but the study also illustrated three ways in which these behavioral categories were difficult to apply in a classroom setting. First, the meaning of the terms proved overly specific. Although each term was observed and was descriptive of the defiant behaviors, I found that application of the terms as defined by Vygotsky at times awkward. Aspects of the terms require the researcher to be specific in the reason for a child's refusal or non-compliance. For example, in observing a child's refusal to comply with a rule or request, the observer must decide whether the child is refusing simply because it was a request (Negativism), or because he is refusing adult assistance (Willfulness) or simply because he is bound to his original plan (Stubborness). Demanding this level of specificity in the terms can be problematic. As an observer, the events preceding the defiance may make it clear as to which term best describes the behavior. However, if the behavior preceding the defiance is not witnessed, it may be impossible to correctly attribute the underlying reason or orientation of the defiance. This difficulty is not as prevalent in the application of protest, despotism and devaluation, because these three behaviors require verbal or physical expression of the behavior, making them easier to confidently assign.

\subsection{Peer Interaction}

Second, because the focus of Vygotsky's approach is the critical behavioral changes in the individual child, the terms and categories he employs do not prove nimble when observing interactions between peers. Because Vygotsky focused on the relationship between adult and child, peer interactions prove awkward in relation to his categories of behavior. Observations from conflicts and arguments between peers frequently showed two sources for the conflicts, each of which interacted with the other. In the observations, children's argumentation with a peer centered around either the desire for a toy or resource (possession), or the desire for a privilege or opportunity (position) resulting in behaviors that can be described using Vygotsky's terms for the critical period. Neither of these conflicts between peers is fully described by the Vygotskian categories, and the result was a difficulty in applying the terms to behaviors. An example of such an observation took place when the teacher was setting up a sprinkler for the children to run through in their bathing suits. The teacher asked a girl to turn on the sprinkler. However, as she approached the knob a boy pushed her away saying, "I got it," and began turning the knob. The girl yelled, "She asked me, not you," and pushed the boy and began to kick him. He pushed back, stating "stop hitting" and the teacher intervened. The source of conflict here was the privilege given to the girl by the teacher. Because the conflict does not involve a single child or child and adult, the conflict and defiance is difficult to assign to a Vygotskian term because of the peer interaction. This could present difficulty in using Vygotsky's terms describing the critical period.

\section{Discussion and Implications}

\subsection{Inter-rater Consistency}

Inter-rater or researcher agreement in assigning the categories presented challenge in applying Vygotsky's 
categories. Because of questions regarding specificity of terms and peer interaction, inter-rater agreement was difficult. The other researcher and I were most similar in our assignments of the terms obstinacy, willfulness and devaluation. My fellow observer over-identified each of these categories by one incident. Protest and despotism show our greatest inconsistency in the assignment of terms. I designated the term protest three more times than did my colleague, and he assigned despotism four more times than I.

Review of both sets of field notes highlighted one possible cause of the inconsistency in these two categories, three of the behaviors I identified as protest were identified by the other researcher as despotism. This highlights the potential difficulty in interpreting and applying these terms, in that despotism requires, according to the term, the researcher to be able to ascribe the desire to dominate others to the child's behaviors. I was less willing to use that term without evidence of such motive. The second researcher judged that desire to subjugate others was implied in the behavior of the children in these situations.

Additional training may address issues relating to consistency between observers, and it is likely that this initial study underestimated the time and nature of the inter-rater training necessary. In the future, video records of the observations may facilitate a greater agreement as well as discussion regarding the coding process and utility of Vygotsky's terms. The findings also highlight the difficulty in applying labels to child behaviors. Because of the complex nature of defiant incidents, children display a wide variety of behaviors rapidly, and the ability to quickly categorize those behaviors with consistency between raters is difficult. This also indicates that teacher use of these categories successfully would depend on a much more developed training regarding the categories and their application. One possible solution may be video recording the observations. By having a video record, observers could view the tapes either independently or together, and the applicability or appropriateness of categories could be discussed.

\subsection{Discussion}

In exploring Vygotsky's terms describing critical behaviors at age three, I found that the behaviors were observable, and descriptive. However, further work is necessary in addressing the role of peers in using this framework to describe behavior at this age as Vygotsky's work and terms apply solely to interactions between adult and child. Additional questions also linger regarding the level of specificity and overlap that exists in the terms which proved problematic in developing agreement between observers. In order to make these terms and their observation useful to classroom teachers, future studies would need to focus on the operationalization and specificity of each term, as well as the level and type of training necessary to achieve inter-rater reliability. Additionally, even when the categories are consistently applied, the next question becomes how can these categories help teachers analyze the behaviors and assist in creating sound strategies that enhance student learning? Non-compliant behavior presents early childhood teachers with challenges, but often the rates of non-compliance and strategies relating to managing and analyzing those behaviors are not the focus of recent scholarship and research (MacKenzie-Keating, McDonald, Tanchak \& Erikson, 1996).

If defiant behavior offers us important clues as to the conflict and development of the child, perhaps Vygotsky's categories of defiant behavior offer some utility for early childhood educators faced with these challenging but important behaviors.

\section{References}

Achenbach T.M., \& Edelbrock C.S. (1983). Manual for the Child Behavior Checklist and Revised Child Behavior Profile. Burlington, VT: University of Vermont.

Atwater, J.B., \& Morris, E.K. (1988). Teachers' instructions and children's compliance in preschool classroom: a descriptive analysis. Journal of Applied Behavioral Analysis, 21(2), 157-67. http://dx.doi.org/10.1901/jaba.1988.21-157

Braungart-Rieker, J.M.,Garwood, M.M., \& Stifter, C.S. (1997). Compliance and noncompliance : The roles of maternal control and child temperament. Journal of Applied Developmental Psychology, 18(3), 411-428. http://dx.doi.org/10.1016/S0193-3973(97)80008-1

Brinbaum, A.S., Lytle, L.A., Hannan, P.J., Murray, D.M., Perry, C.L., \& Forester, J.L. (2003). School Functioning and Violent Behavior Among Young Adolescents: A contextual analysis. Health Education Report, 18, 389-404. http://dx.doi.org/10.1093/her/cyf036

Burton, R., \& Denham, S.A. (1998). “Are you my friend?”: How two young children learned to get along with others. Journal of Research in Childhood Education, 12(2), 210-224. http://dx.doi.org/10.1080/02568549809594885 
Buysse, V., Goldman, B.D., \& Skinner, M. L. (2002). Setting effects on friendship formation among young children with and without disabilities. Exceptional Children, 68(4), 503-517.

Ceballo, R., Ramirez, C., Hearn, K. D., \& Maltese, K. L. (2003). "Community violence and children's Psychological well-being: Does parental monitoring matter?" Journal of Clinical Child and Adolescent Psychology, 32(4), 586-592. http://dx.doi: 10.1207/S15374424JCCP3204_11

Delany-Black, V., Covington, C., Ondersma, S., Nordstrom-Klee, B., Templin, T., Ager, J.,Janisse, J., \& Sokol, R. (2002). Violence Exposure, Trauma, and IQ and/or Reading Deficits among Urban Children. Archives of Pediatric Adolescent Medicine, 156, 280-285.

Denham, S. A., \& Burton, R. (2003). Social and Emotional Prevention and Intervention Programming for Preschoolers. New York: Kluwer Academic/ Plenum Publishers. http://dx.doi.org/10.1007/978-1-4615-0055-1

Dodge, K.A., \& Price, J.M. (1994). On the relation between social information processing and socially competent behavior in early school-aged children. Child Development, 65, 1385-1397. http://dx.doi.org/10.2307/1131505

Honig, A., \& Wittmer, D. (1994). Encouraging positive social development in young children. Young Children, 49(5), 4-12.

Honig, A.S. (2009). Understanding and working with non-compliant and aggressive young children. Early Childhood Development and Care, 179(8), 1007-1023. http://dx.doi.org/10.1080/03004430701726217

Hughes, C., \& Ensor, R. (2006). Behavioural problems in 2-year-olds: links with individual differences in theory of mind, executive function and harsh parenting. Journal of Child Psychology and Psychiatry, 47(5), 488-501. http://dx.doi.org/10.1111/j.1469-7610.2005.01519.x

Izard, C., Fine, S., Schultz, D., Mostow, A., Ackerman, B., \& Youngstrom, E. (2001). Emotion knowledge as a predictor of social behavior and academic competence in children at risk. Psychological Science, 12(1), 18-23. http://dx.doi.org/10.1111/1467-9280.00304

Kalb, L., \& Loeber, R. (2003). Child Disobedience and Noncompliance: A Review. Pediatrics, 111 (3), 641 -652. http://dx.doi.org/10.1542/peds.111.3.641

Keenan, K., \& Shaw, D.S., (1994). The development of aggression in toddlers: a study of low-income families. Journal of Abnormal Psychology, 22, 53- 7.

Kilgore, Kim; Snyder, James; Lentz, Chris (2000). The contribution of parental discipline, parental monitoring, and school risk to early-onset conduct problems in African American boys and girls. Developmental Psychology, 36(6), 835-845. http://dx.doi.org/10.1037/0012-1649.36.6.835

Killen, M., \& Smetana, J. (1999). Social Interactions in Preschool Classrooms and the Development of Young Children's Conceptions of the Personal. Child Development, 70(2), 486-492. http://dx.doi.org/10.1111/1467-8624.00035

Kochanska, G., Coy, K., \& Murray, K. (2001). The Development of Self-Regulation in the First Four Years of Life. Child Development, 72(4), 1091-1107. http://dx.doi.org/10.1111/1467-8624.00336

Kuczynski, L., \& Kochanska, G. (1990). The development of children's noncompliance strategies from toddlerhood to age 5. Developmental Psychology, 26, 398-408. http://dx.doi.org/10.1037/0012-1649.26.3.398

Kuczynski, L., Kochanska, G., Radke-Yarrow, M., \& Girnius-Brown, O. (1987). A developmental interpretation of young children's noncompliance. Developmental Psychology, 23, 799-806. http://dx.doi.org/10.1037/0012-1649.23.6.799

Leonard, R. (1993). Requests, refusals, and reasons in children's negotiations. Social Development, 2(2), 131-148. http://dx.doi.org/10.1111/j.1467-9507.1993.tb00008.x

MacKenzie-Keating, S., McDonald, L., Tanchak, D., \& Erickson, D. (1996). Natural rates of compliant behavior in preschool children in day care settings. Early Childhood Development and Care, 121(4), 91-103. http://dx.doi:10.1080/0300443961240109

Mize, J., \& Cox, R.A. (1990). Social knowledge and social competence: Number and quality of strategies as predictors of peer behavior. The Journal of Genetic Psychology, 151, 117-127. http://dx.doi.org/10.1080/00221325.1990.9914648

Reynolds Keefer, L. (2005). Noncompliant behavior in two-and three-year-olds: A Vygotskian approach. Early Childhood Education Journal, 33(2), 105-111. http://dx.doi.org/10.1007/s10643-005-0001-y 
Schneider-Rosen, K., \& Wenz-Gross, M. (1990). Patterns of Compliance from Eighteen to Thirty Months of Age. Child Development, 61(1), 104-112. http://dx.doi.org/10.1111/j.1467-8624.1990.tb02764.x

Schultz, D., Izard, C., \& Ackerman, B. (2000). Children's anger attribution bias: Relations to family environment and social adjustment. Social Development, 9(3), 284-301. http://dx.doi.org/10.1111/1467-9507.00126

Schultz, D., Izard, C., Ackerman, B., \& Youngstrom, E. (2001). Emotion knowledge in economically disadvantaged children: Self-regulatory antecedents and relations to social difficulties and withdrawal. Development and Psychopathology, 13(1), 53-67. http://dx.doi.org/10.1017/S0954579401001043

Smith, C., Calkins, S., Keane, S., Anastopoulos, A., \& Shelton, T. (2004). The relation of maternal behavior and attachment security to toddlers' emotions and emotion regulation. Research in Human Development, 2006, 3(1), 21-31.

Stifter, C., Spinrad, T., \& Braungart-Rieker, J. (1999). Toward a developmental model of child compliance: The role of emotion regulation in infancy. Child Development, 70, 21-32. http://dx.doi.org/10.1111/1467-8624.00003

Van der Veer, R., \& Valsiner, J. (1994). The Vygotsky reader. Oxford: Blackwell.

Vygotsky, L.S. (1966). Development of the higher mental functions. In A.N. Leont'ev, A.R. Luria, \& A. Smirnol (eds.), Psychological research in the U.S.S.R. Vol. I (pp. 11-45). Moscow: Progress. (Original work published 1931)

Vygotsky, L.S. (1987). The problem of speech and thinking in Piaget's theory. In R.W. Rieber and Claton (Eds.), Problems of general psychology, Vol. 1. Collected works (pp. 53-91). New York: Plenum. (Original work published 1934).

Vygotsky, L.S. (1997a). Analysis of higher mental functions. In R.W. Rieber (Ed.), The history of the development of higher mental functions, Vol. 4. Collected works (pp. 65-82). New York: Plenum. (Original work published 1931).

Vygotsky, L.S. (1998). Development of higher mental functions during the transitional age. In R.W. Rieber(Ed.), Child psychology, Vol. 5. Collected works (pp. 83-149) (M.J. Hall, Trans.). New York: Plenum.(Original work published 1930-1931).

Table 1. Vygotskian terminology for the critical period at age three

\begin{tabular}{|l|l|}
\hline Behavioral Term & Definition \\
\hline Negativism & $\begin{array}{l}\text { The child refuses to do something only because he } \\
\text { was asked to, representing a shift in motivation from a } \\
\text { desire to please to a desire for autonomy. }\end{array}$ \\
\hline Stubbornness & $\begin{array}{l}\text { The child insists on something not only because he } \\
\text { wants it, but because he has demanded it, and is } \\
\text { therefore bound by his initial decision and is unable to } \\
\text { change. }\end{array}$ \\
\hline Obstinacy & $\begin{array}{l}\text { The child shows an impersonal dissatisfaction with } \\
\text { norms or rules, appearing as general non-compliance } \\
\text { with environmental rules and guidelines. }\end{array}$ \\
\hline Willfulness & $\begin{array}{l}\text { The child's desire for independent action and a refusal } \\
\text { of adult assistance. }\end{array}$ \\
\hline Protest & $\begin{array}{l}\text { The child protests or argues decisions, and is in } \\
\text { conflict with the environment and norms. }\end{array}$ \\
\hline Devaluation & The assignment of negative traits to people or objects. \\
\hline
\end{tabular}

Note: Summarized from Vygotsky (1982-1984/1998). The crisis at age three. In R.W. Rieber (Ed.), Child psychology, Vol. 5, Collected works (pp. 283-288). New York: Plenum. 
Table 2. Observational frequency

\begin{tabular}{|l|l|l|l|l|}
\hline & Total & $\begin{array}{l}\text { Researcher } \\
\text { One } \\
\text { Days 1-5 }\end{array}$ & $\begin{array}{l}\text { Researcher } \\
\text { One } \\
\text { Days 6-10 }\end{array}$ & $\begin{array}{l}\text { Researcher } \\
\text { Two } \\
\text { Days 6-10 }\end{array}$ \\
\hline Total number of Incidents & 55 & 29 & 26 & 26 \\
Negativism & 3 & 4 & 2 \\
Stubbornness & 7 & 7 & 5 \\
Obstinacy & 5 & 5 & 6 \\
Willfulness & 3 & 2 & 3 \\
Protest & 6 & 5 & 2 \\
Devaluation & 4 & 2 & 3 \\
Despotism & & 1 & 5 \\
\hline
\end{tabular}

\section{Appendix}

\section{Compliance Behavior Worksheet (CBW)}

Name of Child

Observer

Age

Object(s) Involved

Others Involved

Time / Circumstance

Description

Negativism

Evidence

Stubbornness

Evidence

Obstinacy

Evidence 
Willfulness

Evidence

Protest

Evidence

Devaluation

Evidence

Despotism

Evidence

PRIMARY ORIENTATION (circle one): $\quad$ Adult

Peer Object

C) Reynolds Keefer. 